\title{
Saing-Waing: The Burmese Music Band in Thailand
}

\author{
Dheeraratn Srichuangchote \\ Full-Lecturer, Kanchanaburi Rajabhat University, Thailand
}

\begin{abstract}
This research aimed to investigate the Saing-Waing: The Burmese Music Band in Thailand in order to study the background of Saing-Waing, the music instrument in Saing-Waing and examine the occasion for Saing-Waing applying ethnomusicology. Results showed that Saing-Waing was Myanmar national music band. It had the outstanding and unique melody. Music instruments were Pat-Waing, Chauklongpat, Patma, Sakhun, Maun Sain, Si-wa and Lingwin.. Generally, it was performed in the ceremonies such as ordination ceremony, ear-piercing ceremony, ceremony of spiritual incarcerated or in the festivals for entertainment. Saing-Waing musicians were skillful and expertized in playing to make the beautiful play.
\end{abstract}

Keywords: Saing-Waing, Burmese Music, Myanmar

\section{Introduction}

Music is an art created by human for a long time. Everyone from different races can experience the aesthetics via vision and hearing. It is valuable creation to human. Music is a part of the living of all human races worldwide. Human sooth baby with music, sing the songs in the ceremonies for recreation, prop the show and performance and earn the living. Thus, music plays the similar role everywhere from the origin to the infinite worldwide (Poonpit, 2011).

Myanmar is one the races that has the unique and notable long history music culture. The content narrates the ethnic reflecting through the melody, music instrument, tone and singing. The country has many culture and history stories in Thailand for a long time. Burmese is the group of migrants who have settled in the current location. The golden kingdom was Pagan Kingdom. Later, it became the colony of Great Britain until being independent on 4 January 1948. Myanmar is the kingdom comprises of many races such as Mon, Karen, Tai Yai and Rakhine. Before the independence, the agreement stated that Myanmar government would allow races to participate in administration and government. However, after the independence, Myanmar government did not take the agreement and suppressed all races violently. Races had to evacuate to Thailand, including Myanmar people, through the provinces that were adjacent to Myanmar. When they were in Thailand, some travelled to work in Samut Prakan and Samut Songkram whereas some worked in Kanchanaburi (Boonrod, 2009).

When human move to relocate with any reason, they carry their local culture with them, including music culture for ceremonies and rituals as well as entertainment and recreation in the new habitation. Saing-Waing is Myanmar national music band performing in ceremonies and entertainment events such as temple faire and state functions. At present, Saing-Waing is still popular to perform in ordination ceremony, ear-piercing ceremony, ceremony of spiritual incarcerated, graduation ceremony and to welcome state guests. With this reason, SaingWaing is regarded as Myanmar identity (Oranuch, 1999).

Burmese immigrants apply Saing-Waing to perform in rituals for entertainment and maintain their music culture constantly until today. Thus, the researcher would like to study on the topic "Saing-Waing: The Burmese Music Band in Thailand" to be the guidelines for ethnomusicology research. The objectives of the research were to study the background of Saing-Waing, study the music instruments in Saing-Waing and examine the occasion for Saing-Waing.

\section{Research Methodology}

To study on Saing-Waing: The Burmese Music Band in Thailand, the researcher collected the data from Saing-Waing musicians in Kanchanaburi by the in-depth interview. The objective of the interview was to talk with someone to learn about something in- depth from the person's point of view (H.J. Rubin and I.S. Robin, 2005), which was very useful and typically had high flexibility. In the interview, the researcher met with the 
interviewee in person (Masami, Matthew and Mariah, 2014). Participatory interview was also applied. In this method, the researcher acknowledged any behavior and the act of the phenomenon which you were interested in studying and recording it to describe, analyze, and interpret what it meant (Masami, Matthew, and Mariah, 2014). Observation method, the researcher used own observation and interpretations (of events, persons, or acts) to access the results and conclusion (DeWalt and DeWalt, 2002). Video recording, photographers and documentary research were applied. Concerning documentary research, researches, textbooks, and articles about Burmese, their living, reason of relocation, music culture and performance information, the use of music in rituals were studied. All data from the documents were used to support the research and the data from the field research would be analyzed. The data included the background of Saing-Waing, music instruments in Saing-Waing and the occasion for Saing-Waing.

\section{Results and Discussion}

\subsection{Results of the first objective: The background of Saing-Waing}

In the pamphlet "To know Myanmar", Saing-Waing: Burmese Band, Myanmar Studies Center, Nare asuan University (Oranuch, 1999) stated that in The Great Royal Chronicle of the Glass Palace mentioned that in 1544, Tabinshwehti of Taungoo moved the army to Shan. At Salin, he settled the army at the waterside where there was the pagoda ceremony. When Tabinshwehti heard the music, he asked his followers and found out that it was the sound of Pat-Waing. After the triumph, he ordered to bring the music band back with him to Taungoo. Consequently, it was assumed that Saing-Waing was brought to the royal since then. Saing-Waing comprised of the drums, approx. 18-24 drumps hanging in circle on the lath. The drum was the type that was used in the royal court and played for general people. Saing-Waing that was used in the royal court had the pattern with the glass and covering with gold. Saing-Waing with white glass was "Wong Ratch Sam Nak Petch", Saing-Waing with the red glass was "Wong Ratch Sam Nak Tabtim" and the Saing-Waing with assorted colors was "Wong Ratch Sam Nak Kao Rattanachat" (U Win Pe, n.d.).

\subsection{Results of the second objective: Music instruments of Sing-Waing}

Burmese who migrated from Myanmar brought Saing-Waing into Thailand. They brought only the main music instruments because they did not have enough musicians. However, it did not damage the song pattern. (SuNgae, 2016, 5 July. Interview). From the field research in Kanjanaburi, it was found that there were 9 instruments of Saing-Waing consisted of instruments from Membranophon. Pat-Waing which was the roundeddrum with 17 small drums inside hanging from the smaller to the bigger one. The outer part was decorated with beautiful glass pattern. The musician sat on the chair in the circle, hitting the drum with fingers in melodies. Pat-Waing was the key main music instrument of Saing-Waing. Chauklongpat was the drum with 6 drums placing from smaller to the bigger one. There was the long stick tapping with the leather on both sides to adhere all six drums while playing. Each drum gave different tone. To play it, hit the drum with the palm. Patma was a large two-sided drum made from hard wood standing on the wooden stand. Hit on the two sides of drum with palms. Sakhun was a two-sided drum, similar to Patma but smaller. It was made from the hard wood standing on the wood stand. Hit on the two sides of drum with palms. Sito was the drum with two drums. Place the drum on the floor and hit the two sides of drum with drumstick (Pho, 2016, 6 July. Interview).

Music instruments from Idiophone: Maun Sain was 18 balls made from metal with the button in the center to hit. Both sides had the rope to tie with wooden rail. There were 5 rectangle rails. Hit the instrument with the wood stick. Si-Wa: "Si" made from metal while "Wa" made from rectangle hard wood. To play it, hit with wood stick. Lingwin made from metal placing on the wood log adhering with nails. To play it, hit with wood stick (Teryingwae, 2016, 5 September. Interview). 


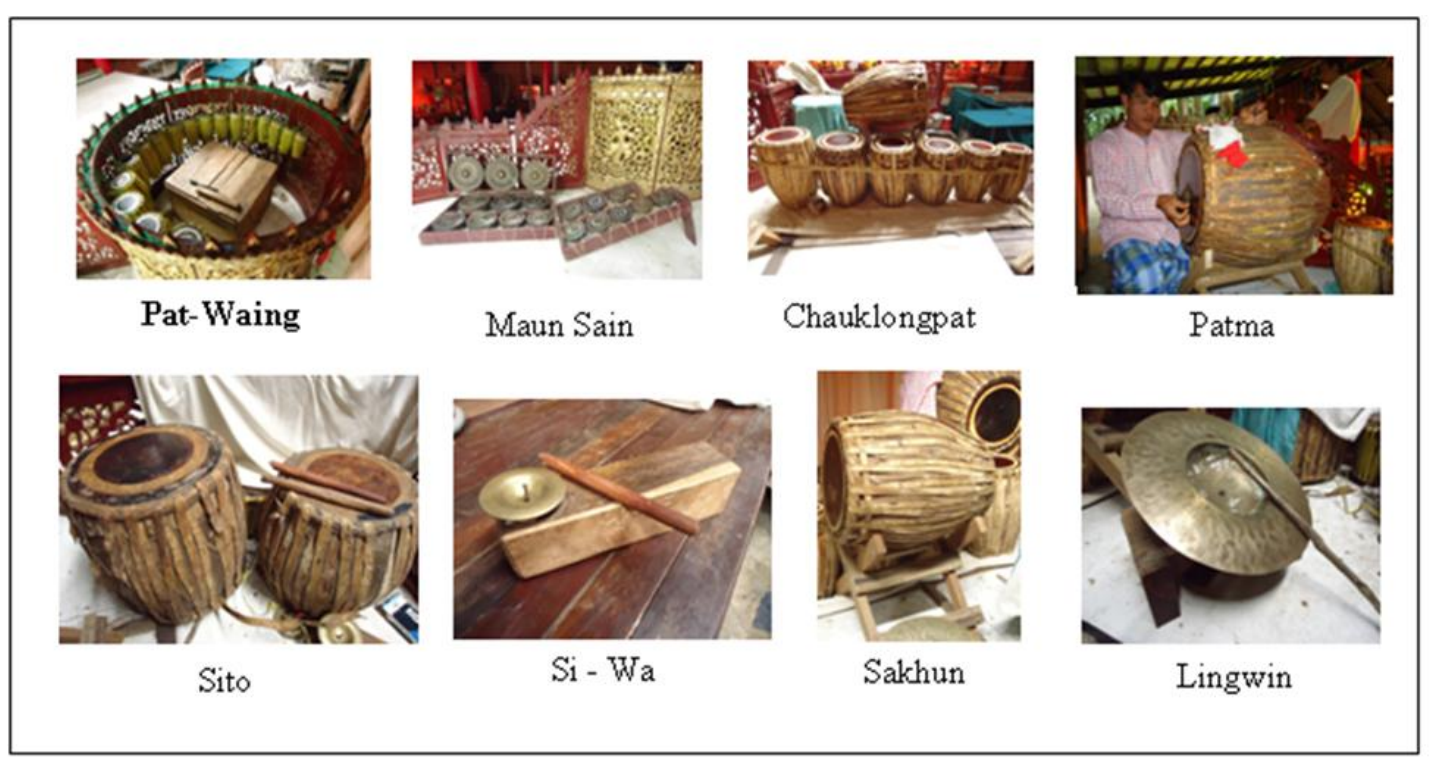

Fig. 1: "Music instruments of Sing-Waing"

\subsection{Results of the third objective: The occasion for Saing-Waing requirements}

From the field research on Saing-Waing in Kanchanaburi, it was found that Burmese performed SaingWaing in various occasions such as ordination ceremony, ear-piercing ceremony, ceremony of spiritual, Burmese dancing, for entertainment and recreation and for entertaining foreign tourists in resorts in Kanchanaburi and the nearby provinces. It was the career generating income to Burmese musicians (Mone, 2016, 13 September. Interview).

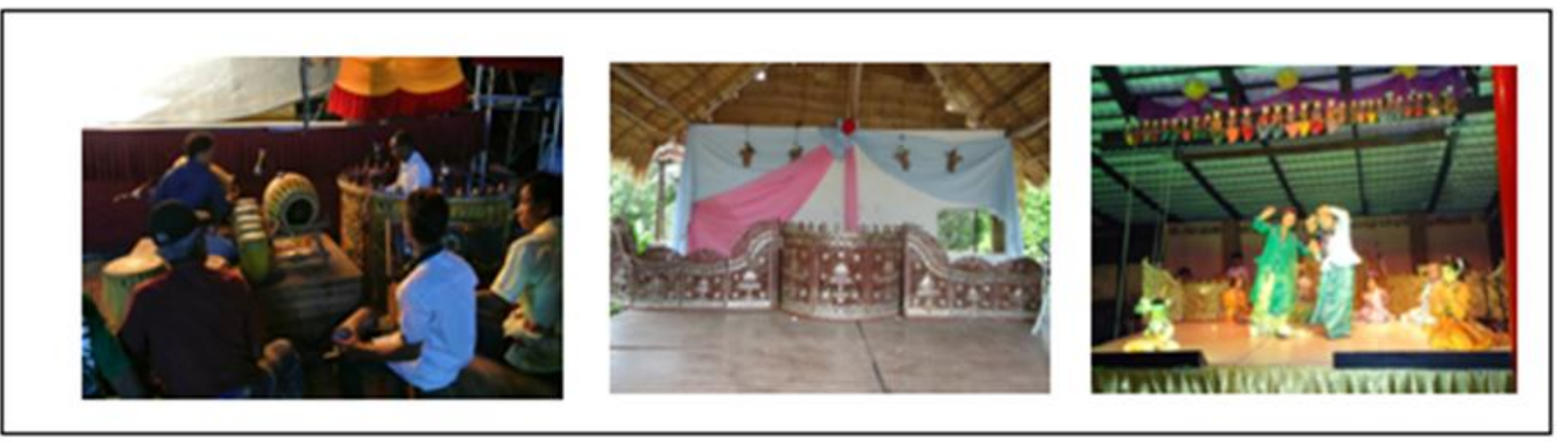

Fig. 2: "The occasion for Saing-Waing requirements"

\section{Conclusion}

Saing-Waing was the significant music band of Burmese. In general, Burmese performed Saing-Waing in rituals and occasions. It was consistent with Oranuch who stated that Saing-Waing was the Myanmar national music band performing in royal ceremonies and entertainment events, state functions and public functions (Oranuch, 1999). Currently, Saing-Waing is still popular to perform in ordination ceremony, ear-piercing ceremony, ceremony of spiritual, graduation ceremony and the welcoming state guests. Saing-waing consisted of Pat-Waing, Chauklongpat, Patma, Sakhun, Maun Sain, Si-wa and Lingwin. To perform Saing-Waing beautifully, the players should be skilfful in order to entertain the audiences cheerfully. Therefore, Sing-Waing was the music band that contained Myanmar identity.

\section{Acknowledgements}

I would like to thank you: 
1. Kanchanaburi Rajabhat University

2. Assistant Professor Pannipa Kaveetanathum

3. Burmese performer in Saing-Waing who are interviewee

\section{References}

[1] Boonrod Chalarags, "Life Style, Background and the Way of Life of the Minority Groups in Kanchanaburi," Kanchanaburi Rajabhat Univ., Kanchanaburi, Thailand, 2009.

[2] DeWalt, Kathleen M. \& DeWalt, Billie R, Participantobservation: a guidefor fieldworkers. Walnut Creek, CA: AltaMira Press, 2002

[3] Interview with Mone, Performer, River Villa Resort, 13 September 2016.

[4] Interview with Pho, Performer, Wangvivaegaram Temple, 6 July 2016.

[5] Interview with SuNgae, Performer, Myanmar Village-Somjainuek Market, 5 July 2016.

[6] Interview with Teryingwae, Performer, Myanmar Village- Phunamron Rattanakeeri, 5 September 2016.

[7] Masami Nishishiba, Matthew Jones and Marish Kraner, Research Methods and Statistics for Public and Nonprofit Administrators: A Practical Guide. USA: Sage Publications, 2014

[8] Oranuch Niyomtham, "Saing - Waing: Pi-Phat in Myanmar [Pamphlet]," Knowing Myanmar (10). Phitsanulok: Trakoonthai Printing, 1999

[9] Poonpit Amatyakul, The 16th Silpa Bhirasri's Speech Year 2011. The formation of modern thai song Concepts in Musicology, Bangkok: Amarin Printing \& Publishing Public Company Limited, 2011

[10] Rubin, H.J., and I.S. Rubin, Qualitative Interviewing: The Art of Hearing Data. 2d ed. Thousand Oaks, CA: Sage Publications, 2005

[11] https://doi.org/10.4135/9781452226651

[12] U Win Pe, Myanmar Traditional Musical Instruments, Myanmar: Ministry Of Culture Fine Arts Department, n.d. pp.viii-xiii 